\title{
RUSSIAN GENDER RELATIONS IN EDUCATIONAL MATERIALS ON RFL AS A SUBJECT OF REFLECTION IN THE MUSLIM AUDIENCE
}

\author{
Natalya A. Vostryakova \\ Volgograd State Technical University, Volgograd, Russia
}

\begin{abstract}
The article analyzes the textbook of the Russian language "The Road to Russia" by V.E. Antonova, M.M. Nakhabina, M.V. Safronova, A.A. Tolstykh, which is in demand at the elementary, basic and first certification levels of training of foreigners in Russia and abroad. Special attention is drawn to the speech practice and visual materials of this textbook, that represent gender relations in Russia, which might be ambiguously perceived by students who profess Islam. It is shown that when comprehending such materials, students often do not take into account the traditional moral values of the Russians and make inadequate moral conclusions. The necessity of considering these issues is explained by the fact that this textbook is applicable to an "ideal foreigner"; it does not take into account the confessional characteristics of students and significant differences in the organization of life in different countries. The article distinguishes particular texts and topics of the textbook, the study of which should be accompanied by special cultural commentary of the teacher, as well as speech material that might be excluded from the educational process, since its presentation in the Muslim audience is not appropriate. A reasoned conclusion is drawn on the necessity of compiling a textbooks aimed at forming a positive opinion on Russia among foreign Muslim students and harmonizing relations between speakers of different faith-based cultures.
\end{abstract}

Key words: cross-cultural communication, Russian as a foreign language, RFL, Russian gender relations, Educational Linguistics, Islam, educational text, educational dialogue.

Citation. Vostryakova N.A. Russian Gender Relations in Educational Materials on RFL as a Subject of Reflection in the Muslim Audience. Vestnik Volgogradskogo gosudarstvennogo universiteta. Seriya 2. Yazykoznanie [Science Journal of Volgograd State University. Linguistics], 2019, vol. 18, no. 3, pp. 103-115. (in Russian). DOI: https://doi.org/10.15688/jvolsu2.2019.3.8

УДК $811.161 .1 ’ 243$

Дата поступления статьи: 11.01.2019

ББК 81.411.2-99

Дата принятия статьи: 26.08.2019

\section{РУССКИЕ ГЕНДЕРНЫЕ ОТНОШЕНИЯ В УЧЕБНЫХ МАТЕРИАЛАХ ПО РКИ КАК ПРЕДМЕТ ОСМЫСЛЕНИЯ В МУСУЛЬМАНСКОЙ АУДИТОРИИ}

\author{
Наталья Анатольевна Вострякова \\ Волгоградский государственный технический университет, г. Волгоград, Россия
}

\begin{abstract}
Аннотация. В статье анализируется учебник русского языка В.Е. Антоновой, М.М. Нахабиной, М.В. Сафроновой, А.А. Толстых «Дорога в Россию», востребованный на элементарном, базовом и первом сертификационном уровнях обучения иностранцев в России и за рубежом. Обращается внимание на его речевые и визуальные материалы, представляющие русские гендерные отношения и неоднозначно понимаемые студентами, исповетрадиционные нравственные ценности россиян и делают неадекватные моральные выводы. Включение этих материалов объясняется тем, что данный учебник является универсальным, ориентированным на «абстрактнизации жизни разных стран. В статье определяются отдельные тексты и темы учебника, изучение которых д должно сопровождаться специальными культурологическими комментариями преподавателя, а также речевой материал, который можно исключить из образовательного процесса, поскольку его представление в му() сульманской аудитории нецелесообразно. Делается аргументированный вывод о необходимости создания учеб-
\end{abstract}


ных пособий, нацеленных на формирование положительного мнения иностранных студентов-мусульман о России и гармонизацию отношений между носителями разных конфессиональных культур.

Ключевые слова: межкультурная коммуникация, русский язык как иностранный, РКИ, русские гендерные отношения, лингводидактика, ислам, учебный текст, учебный диалог.

Цитирование. Вострякова Н. А. Русские гендерные отношения в учебных материалах по РКИ как предмет осмысления в мусульманской аудитории // Вестник Волгоградского государственного университета. Серия 2, Языкознание. -2019. - Т. 18, № 3. - C. 103-115. - DOI: https://doi.org/10.15688/jvolsu2.2019.3.8

\section{Введение}

В настоящее время основной иностранный контингент подготовительных факультетов российских вузов - граждане стран Азии и Африки. Большинство из них по своему вероисповеданию - мусульмане. Однако особенности преподавания русского языка в такой аудитории в отечественной лингводидактике исследованы мало, а осуществление эффективной межкультурной коммуникации на уроке русского преподавателя-иноверца (или атеиста) со студентами-мусульманами и достижение последними высоких академических результатов обучения, как показывает практика, весьма проблематичны.

В большинстве случаев на подготовительных факультетах студенческие группы формируются без учета национальной и религиозной принадлежности учащихся. Национально-ориентированных учебников РКИ мало, и используются они редко. Специальных изданий, ориентированных на мусульманскую аудиторию, на сегодняшний день не существует. Поэтому учебный процесс, в который включены мусульмане, организуется, как правило, без учета их религиозной специфики, с опорой на универсальные учебники и пособия по РКИ, являющиеся для студентов главным источником знаний о русском языке и России. При этом социокультурная информация о нашей стране, заключенная в учебниках, может быть негативно воспринята учащимися данной конфессиональной группы, что снижает эффективность обучения.

\section{Критическое восприятие студентами-мусульманами русских гендерных отношений при изучении учебника «Дорога в Россию»}

Как показали наши многолетние наблюдения за студентами-мусульманами (из Ира- ка, Ирана, Йемена, Саудовской Аравии, Палестины, Египта, Судана, Марокко, Турции, Афганистана, Пакистана, Нигерии, Гвинеи, Гвинеи-Бисау, Ганы, Кении, Бангладеш, Нигерии, Индонезии), обучавшимися на подготовительном факультете Волгоградского государственного технического университета в 2004-2019 гг., русские гендерные образы и отношения, представленные в универсальных учебниках и пособиях по РКИ, не всегда понимаются и позитивно воспринимаются учащимися. Проиллюстрируем данное утверждение на примере популярного учебника В.Е. Антоновой, М.М. Нахабиной, М.В. Сафроновой, А.А. Толстых «Дорога в Россию», используемого при обучении РКИ на элементарном, базовом и первом сертификационном уровнях (Антонова и др., 2003а; Антонова и др., 2004; Антонова и др., 2006а; Антонова и др., 2006б).

Читая тексты и выполняя упражнения из данного учебника, иностранцы знакомятся с лучшими представителями российских мужчин и женщин, которыми мы гордимся (писателем П.П. Бажовым, поэтом Ф.И. Тютчевым, педагогом Н. Нестеровой, фотографом Е. Рождественской и др.). При этом если личность известного писателя А.П. Чехова (Антонова и др., 2006а, с. 52-56) всегда вызывает у них интерес и восхищение, то профессиональная деятельность «героя нашего времени» С. Бодрова (Антонова и др., 2004, c. 174-175) кажется им сомнительной для мужчины и не достойной внимания. Процитируем слова нашего студента из Афганистана: «Почему я должен учить текст об этом артисте? Если бы он был ученым, я согласен, но артист...».

Такая реакция объясняется тем, что в исламе отношение к артистам, деятелям искусства, театру, кино и телевидению неодобрительное, поскольку они способствуют праздному времяпрепровождению и отвлекают людей от служения Всевышнему. Поэтому 
студенты-мусульмане обычно не выбирают профессии из сферы искусств и культуры. Ценность искусства для них зависит от его пользы и соответствия законам шариата. Искусство приветствуется, если утверждает положительные исламские идеалы, гармонию в человеке и обществе. Если же оно пропагандирует отрицательные явления в человеческом обществе, демонстрирует нарушение норм исламского поведения - его осуждают (см.: Каково отношение ислама к театру? 09.10.2014. URL: https://islam-today.ru/veroucenie/ vopros-otvet/kakovo-otnosenie-islama-k-teatru). Вследствие этого сценарии спектаклей и фильмов в мусульманских странах редактируются на предмет соответствия законам шариата.

Не меньшие сложности этического характера возникают в мусульманской аудитории при знакомстве с Мисс Вселенной Оксаной Федоровой (Антонова и др., 2004, с. 221) и топ-моделью Натальей Водяновой (Антонова и др., 2006б, с. 163-164). Признать уважаемым их род занятий многие учащиеся не готовы, так как модельный бизнес, с точки зрения ислама, является индустрией греха, которая провоцирует порочное поведение мужчин, не уважает честь женщин и разрушает женские жизни.

Модельному бизнесу европейских стран мусульмане предлагают свою «правильную» альтернативу. Модная одежда, по их мнению, должна защищать женщину от похотливых взглядов и соответствовать нормам ислама. Девушки-модели должны демонстрировать коллекции в стиле «хиджаб», но присутствовать при этом могут только зрительницы-женщины (подробно см.: Раджабов Хаджи-Мурат. Разбитые мечты, или Индустрия модного греха. 06.04.2012 г.).

Неоднозначно воспринимается студентами и активная роль женщины в общественной жизни, типичная для российской действительности, продемонстрированная в «Дороге в Россию» на примере судеб княгини Ольги, Е. Дашковой, М. Тенешевой, А. Вавиловой, Л. Слиски и других героинь. Это может выявляться при обсуждении текстов о них, а также выполнении одного из заданий учебника (Антонова и др., 2004, с. 159), в котором учащимся предлагается прочитать фрагменты статей из молодежной газеты и выразить свое отношение к нашим современницам Марине и Даше: Марина - студентка, мечтает стать образованным человеком и работать экскурсоводом в Москве. 19-летняя Даша, не выбрав профессии, выходит замуж. Она хочет всегда быть стройной и красивой и знает, что будет хорошей женой и хозяйкой. Высказывая мнение об этих девушках, студенты-мусульмане не критикуют Дашу. С их точки зрения, она выбирает достойный жизненный путь, поскольку жизнь женщины легче, чем мужчины, ей не обязательно зарабатывать самой и, следовательно, нет необходимости получать образование. В России же качественное образование считается немаловажным условием жизненного успеха человека вне зависимости от его гендерной принадлежности.

В учебнике «Дорога в Россию» студентам также предлагаются диалоги и упражнения, в которых рассказывается о совместной учебе юношей и девушек в российском университете, их распорядке дня, общем студенческом досуге - походах в гости, кафе, на дискотеку, пляж и т. д. Причем в целях обеспечения доступности и наглядности такие материалы часто сопровождаются иллюстрациями, нейтральными с точки зрения носителей русской культуры, но неэтичными по мнению мусульман: на них юноши могут изображаться в пижаме, нижнем белье (по утрам и вечерам), плавках (на пляже) и даже полунагими (при иллюстрации словосочетания мыться под душем) (Антонова и др., 2003a, с. 271; Антонова и др., 2006а, с. 22, 23, 28). Девушки представлены на рисунках в европейской одежде, без хиджаба, часто - в коротких платьях и даже бикини (на пляже). Они игриво улыбаются молодым людям (Антонова и др., 2006а, с. 28), танцуют с ними и даже целуются (Антонова и др., 2003а, с. 133; Антонова и др., 2006а, с. 24).

Нередкая для студенческой жизни ситуация знакомства лиц противоположного пола описывается в «Дороге в Россию» неоднократно. При этом возмущение вызывает у студентов-мусульман диалог из учебника, который предлагается учащимся на базовом уровне для аудирования:

- Виктор, посмотри, с какой симпатичной девушкой танцует Андрей. Ты не знаешь, кто это?

- Знаю, это моя младшая сестра. 
- Познакомь меня со своей младшей сестрой. Она мне очень понравилась (Антонова и др., 2004, c. 158).

По словам учащихся из Афганистана, Пакистана, Ирака, Ирана, Саудовской Аравии, друг Виктора проявляет дерзость. Его слова компрометируют честь девушки, поэтому Виктору следует не знакомить друга с сестрой, а немедленно проучить парня, применив физическую силу.

Нередко демонстрируется в анализируемом учебнике ситуация свидания, способы приглашения на него и поведение на нем. При этом юноши предстают в ней не только влюбленными, романтичными и терпеливыми, но и весьма легкомысленными. Ср.:

1) - Кому позвонить? Анне? Марии? Наташе? (Антонова и др., 2003a, с. 272);

2) - Кого ты ждешь, Таню?

- Нет, сегодня я жду Веру (Антонова и др., 2003a, c. 151).

Девушки в «Дороге в Россию», договариваясь с юношами о возможной встрече, ведут себя уверенно, смело высказывают свою точку зрения и подчас даже мучают поклонников (Антонова и др., 2004, с. 251; Антонова и др., 2006а, с. 58). Смущение у студентов вызывает диалог Анны и Антона (Антонова и др., 2003a, с. 222), в котором капризная Анна под разными предлогами отказывается от свидания с Антоном, но с удовольствием соглашается пойти с ним в гости к Ивану, тем самым демонстрируя свои истинные предпочтения. Еще большее замешательство возникает у мусульман при чтении диалога темнокожего Роберта и Алены, в котором он настойчиво и нагло (с их точки зрения) приглашает девушку на свидание и получает многократный завуалированный отказ. На вопрос авторов учебника о том, нравится ли Роберт Алене, иностранцы обычно отвечают правильно. Могут они догадаться и о причинах непрямого отказа девушки. Однако сама тематика такого диалога и постыдные, «низменные» устремления Роберта вызывают у них чувства неловкости и замешательства.

Более экстравагантные способы приглашения на свидание и знакомства описываются в учебных текстах «Жди меня», «Позвони мне» и в безымянном тексте из субтеста по «Лексике. Грамматике» базового уровня (Антонова и др., 2004, с. 33-34, 110-111, 219). При этом если персонажи из первых двух текстов удивляют студентов-мусульман своей смелостью и находчивостью (для поиска любимых они используют телевизионную программу или уличную рекламу), то герои последнего текста могут вызвать у них осуждение:

Когда я служил в армии, я переписывался с одной девушкой. Эту девушку я никогда не видел и не знал раньше. Просто она писала мне хорошие, нежные письма (Антонова и др., 2004, с. 219).

Подробно ситуация свидания описывается в двух текстах учебника - «Измайловский парк» и «Завтрак». В Измайловском парке гуляют молодой человек и симпатичная девушка (словесное описание их прогулки дополняет иллюстрация, изображающая целующихся влюбленных) (Антонова и др., 2003a, с. 133). «Почему рядом с ними нет отца, брата или другого надежного свидетеля? Как они могли прийти туда вдвоем?» - такие вопросы задают при чтении этого текста студентымусульмане.

В тексте «Завтрак» (Антонова и др., 2004, с. 68-70) описывается, как женщина по имени Клара, не будучи знакомой с молодым писателем Александром Орловым, отправляет ему письмо, в котором назначает встречу в дорогом ресторане, чтобы поговорить о его новой книге. Там она заказывает себе дорогие блюда, а несчастный писатель, оплачивая их совместный завтрак, остается без средств к существованию.

Поведение этих героев озадачивает студентов из мусульманских и немусульманских стран. Приведем типичные реакции: «Почему они встречались вдвоем?; Почему писатель заплатил за Клару, для чего? Ведь она немолодая и некрасивая...; Почему Клара не заплатила за себя сама?». Ответ на последний вопрос находим в исследованиях по русской культуре и этикету: «Завоевать расположение русской женщины можно при условии, если вы ведете себя с ней как джентльмен, как покровитель и защитник. < .. > Если вы ухаживаете за девушкой, то должны быть готовы платить за нее в кафе, ресторане, кино, театре и т. д. В России это воспринимается 
“слабым” полом как... нечто само собой разумеющееся. <..> ...они [русские женщины] расценивают мужскую готовность платить за них как свидетельство надежности, опоры, истинно джентльменского отношения к ним. <...> Как правило, женщины, соглашаясь, чтобы за них платили, не собираются при этом брать на себя никаких обязанностей... флиртовать и т. д. <..> В России женщина хочет быть независимой, но предпочитает, чтобы при этом за нее платили. Такая позиция уникальна, поскольку отличается как от принятых на Западе норм поведения, так и от восточных традиций» [Сергеева, 2005, с. 109-110].

Иностранцы не знают данных особенностей русского этикета и не считают, что мужчины обязаны платить за неприятных им незнакомых женщин. Они не понимают, что в тексте «Завтрак» молодой писатель Орлов, несмотря на бедственное материальное положение, стремился сохранить свою репутацию джентльмена. Клара же, догадываясь об этом обстоятельстве, эксплуатировала его порядочность. Поэтому вина ее, с точки зрения русских, не в том, что она позавтракала за чужой счет, а в том, что чересчур смело для русской женщины назначила свидание незнакомому мужчине и, несмотря на намеки, не захотела уменьшить его расходы, отказавшись во время завтрака от дорогих блюд в пользу дешевых.

Тема одиночества, долгого ожидания любви поднимается в текстах «Свадебный марш» и «Портрет» (Антонова и др., 2004, c.177-178, 243-244). Поскольку для понимания гендерных отношений нужна социальная зрелость, эти тексты сложны для вчерашних школьников, которыми являются в большинстве своем студенты подготовительного факультета.

Рассказанные в них истории имеют хэппи-энд. Настоящую любовь персонажи находят в самых демократичных местах (в подземном переходе, около метро) и быстро проникаются доверием к своим избранникам. При этом особенно шокирует учащихся поведение одинокой Наташи, которая не только инициировала знакомство с незнакомым мужчиной, пришедшим на свидание к другой женщине, но и попросила его прилюдно себя поцеловать, чтобы ввести в заблуждение подруг и получить их одобрение.
Заметим, что в знак благодарности за подаренную жизнь целует доктора Булгакова и пациентка из контрольного текста базового уровня субтеста «Говорение» (Антонова и др., 2004 , с. 240-241). Ее поцелуй кажется невинным и естественным русским людям, но также не одобряется мусульманами.

Неоднократно изображается в учебных текстах «Дороги в Россию» и идеальная русская семья, поскольку формирование умения рассказывать о семье (своей, друга, известной личности) предусматривается программой первого сертификационного уровня обучения: это Антон и его родственники из текста «Моя семья», дружные и любящие бывать на концертах Наташа и Антон, супруги Пушкины, Чеховы, Стриженовы, многодетная семья художницы Марии Елисеевой (Антонова и др., 2003a, с. 73, 192-193; Антонова и др., 2004, с. 100-101; Антонова и др., 2006а, с. 55-56, 59; Антонова и др., 2006б, с. 13) и др. Знакомясь с такими персонажами, учащиеся легко осмысляют идеал русской семьи, русские семейные ценности.

Тема семьи, трудностей ее создания и укрепления представлена в «Дороге в Россию» также на материале адаптированных публицистических и художественных текстов. Так, читая рассказ А.П. Чехова «С женой поссорился» (Антонова и др., 2006б, с. 30-31), учащиеся могут задуматься над тем, почему так легко возникают семейные ссоры (отметим, что юмористический подтекст этого произведения прекрасно осознается студентами внезависимости от их религиозной принадлежности). Воспринимая газетные тексты, они должны поразмышлять над тем, почему японский миллионер Ютака Хориз поселился в России и какой должна быть его новая русская жена (Антонова и др., 2004, с. 170-171), сравнить семейные традиции России, Италии, Америки и рассказать о семейных традициях своей страны и семьи (Антонова и др., 2006а, с. 45-46), обсудить необходимость существования центров планирования семьи и даже выразить мнение по поводу необходимого количества детей в современной семье (Антонова и др., 2006а, с. 11-12).

Все адаптированные публицистические тексты имеют небольшой объем и написаны доступно для студентов первого сертифика- 
ционного уровня обучения. Однако работа с ними в мусульманской аудитории затруднена. По-видимому, они не вполне соответствуют возрастным интересам студентов (гендерную проблематику студенты разного возраста осмысляют по-разному). Иностранцы 18-20 лет еще не задумываются серьезно над семейными проблемами и не готовы их обсуждать. Взрослые же учащиеся (которых обычно немного) часто отказываются разговаривать о своей личной жизни публично, особенно о разводах, конфликтах, многоженстве и пр.

Кроме того, трудности в обсуждении данных текстов и изучении темы «Семья» могут быть обусловлены требованиями мусульманского этикета, который не допускает расспросов о женской части семьи. Показательны в этой связи результаты анкетирования Т.А. Кротовой, проведенного в 20022014 гг. среди арабских студентов (из Сирии, Йемена, Омана, Ливана, Туниса и Марокко) от 18 до 32 лет, которые изучали русский язык на разных этапах в России, Великобритании, Польше и Германии. Лишь 52 \% опрошенных ею респондентов выразили готовность обсуждать свою семью с преподавателем и студентами из других стран, 38 \% заняли нейтральную позицию, 5 \% ответили, что им будет неприятно подобное обсуждение. При этом отвечать на вопросы о жене, матери и сестре категорически не готовы 19 \% опрошенных, 5 \% сказали, что постараются изменить тему разговора, а $19 \%$ - что затруднятся ответить [Кротова, 2014, с. 93, 96-97; 2015, с. 27, 72-73,108].

Дискомфорт в мусульманской аудитории возникает при необходимости изучать тексты о женском кокетстве, внебрачных связях. Студенты считают такие явления непростительными. Резкое осуждение у них вызывает, например, замужняя Наташа из текста «Отдых в Ялте» (Антонова и др., 2003а, с. 311), флиртующая с двумя молодыми людьми в отсутствие мужа. Неодобрительно относятся они и к роману А. Ахматовой с художником Б. Анрепом, который довольно корректно описывается в тексте о поэтессе (Антонова и др., 2004, c. 123-124).

Сложно обсуждать с мусульманами также поведение «целеустремленного человека» Оли Журановой из текста «Рождественские каникулы» (Антонова и др., 2006б, с. 136-140), которая терпит любовное фиаско, приезжая из маленького города в Москву. Мечтая стать женой богатого человека, она вступает в связь со своим немолодым начальником и остается без работы и денег. На наш взгляд, данный текст можно исключить из образовательного процесса в мусульманской аудитории, поскольку он не сообщает ценной культурологической информации и дискредитирует представителей русской культуры в глазах иностранцев.

Отметим, что сходные наблюдения имеются и у других исследователей. Так, сложности у турецких филологов университета Фатих (изучающих русскую литературу на языке оригинала в своей стране) вызвали роман Л.Н. Толстого «Анна Каренина» и рассказ А.П. Чехова «Дама с собачкой», которые затрагивают тему кризиса семейных отношений и супружеских измен. Как отмечают И.Ш. Юнусов, М. Озтюрк и К. Юнал, студенты понимали прелесть и ценность любви, но резко осуждали адюльтеры литературных героев (подробно см.: [Юнал, Юнусов, 2015, c. 93; Юнусов, Озтюрк, 2012, с. 163]). Анализируя высказывания турецких учащихся о героях Л.Н. Толстого и А.П. Чехова, Ш. Юнусов и К. Юнал пришли к выводу, что их религиозное мировоззрение детерминировало интерпретацию ими супружеского конфликта в художественных текстах [Юнал, Юнусов, 2015 , с. 95]. Турецкие юноши и девушки единодушно считали, что семейный долг всегда должен уступать место любви и что герои этих произведений обманывают не только супругов, но и самих себя, так как за греховную связь им придется отвечать перед Всевышним.

Причем, в отличие от русских авторов и читателей, они не склонны были оправдывать или прощать недостойное поведение Анны Карениной или Анны Сергеевны и Дмитрия Дмитрича Гурова из рассказа А.П. Чехова, поскольку прелюбодеяние для мусульман тяжкий грех, стоящий в одном ряду с многобожием и убийством, его искупление невозможно [Юнал, Юнусов, 2015, с. 91-92].

Более того, осмысляя роман Л.Н. Толстого «Анна Каренина» и рассказ А.П. Чехова «Дама с собачкой», турецкие учащиеся отказывались признавать эстетическую цен- 
ность этих классических русских произведений, поскольку они повествовали о неприличных, аморальных историях. Это объясняется тем, что, с точки зрения ислама, любой письменный текст (в отличие от устного) обладает непререкаемым авторитетом и потому должен учить образцовому поведению. Он не может и не должен учить плохому, а безнравственное не может быть эстетически совершенным [Юнал, Юнусов, 2015, с. 92-95]. Следовательно, чтобы художественный текст представлялся значимым для учащихся, исповедующих ислам, он должен утверждать достойное нравственное поведение героев.

В некоторых случаях специфика мусульманского отношения к гендеру не позволяет понять юмор. Например, преподаватель русского языка Е. Крисанова обратила внимание на особенности восприятия студентами учебного текста «Счастливая скамейка». Сюжет текста таков: молодой человек из-за начавшегося на улице дождя вынужден был принести в свой дом чужого неизвестного ребенка и объяснять его появление родителям. Студенты-иранцы не могли допустить мысли о возможности внебрачной связи героя и потому не восприняли юмор рассказа: «Мы не поняли. Родители подумали, что он женился, а им не сказал?» (Крисанова Е. Братья-мусульмане. 22.01.2014. URL: http://ohrussian.com/ bez-rubriki/bratya-musulmane.html).

Обобщая наши наблюдения за восприятием студентами-мусульманами материалов учебника «Дорога в Россию», подчеркнем, что сегодня он является одним из лучших, используется во многих странах мира (России, Иране, Египте, Китае, Вьетнаме, Индии и др.), имеет национальные версии с грамматическими комментариями, которые облегчают работу с ним. В частности, для мусульман представляют интерес арабская и персидская версии учебника (Антонова и др., 2001), грамматический комментарий и словарь для говорящих на персидском языке (Антонова и др., 2003б).

Неприятие рассматриваемой конфессиональной аудиторией учебных текстов и диалогов можно наблюдать в отношении материалов многих современных учебников и пособий по РКИ. Мусульмане не только проявляют любопытство по отношению к принци- пиально новому для них образу жизни, но и испытывают растерянность, неловкость, смущение, замешательство, возмущение. В некоторых случаях они могут выражать насмешку и даже презрение по отношению и к персонажам текстов, и к представителям русской культуры в целом.

Заметим, что негативная реакция учащихся, по-видимому, еще ярче проявляется в процессе преподавания РКИ в традиционных мусульманских странах. Она порождает необходимость для преподавателей тщательно анализировать материалы универсальных учебников и пособий с точки зрения нравственно-этической ценности для мусульман и отбирать издания таким образом, чтобы уменьшить культурные конфликты и подчеркнуть сходство изучаемой и родной культур [Сейд, Муса, 2015, с. 267-269]. В этой связи, думается, не случайно в вузах Ирана не используют учебник «Дорога в Россию» в полном объеме: на элементарном уровне он применяется, а на базовом и первом сертификационном - нет [Дастамуз, 2017, с. 13-14; Шоджаи, 2007, с. 96].

\section{Нормы гендерной коммуникации с точки зрения мусульман}

Проблема восприятия студентами-мусульманами русских гендерных отношений, представленных в универсальных учебниках и учебных пособиях по РКИ, не была предметом специальных научных исследований. Нам удалось обнаружить лишь несколько замечаний, более или менее тесно связанных с ней.

С точки зрения мусульман, достойными и рекомендуемыми к использованию на всех уровнях образования являются учебные пособия, в которых материал освещается в соответствии с исламской системой ценностей, а научные факты подкрепляются кораническими аятами и сунной [Кротова, 20126, с. 356]. Однако универсальные учебники РКИ ориентированы на обучение студентов в светской России и обычно не подразумевают обращение к религиозным текстам и лексике. Они презентуют современную русскую разговорную речь, российскую действительность и традиционные семейные и гендерные отноше- 
ния, принятые в нашей стране. В целях обеспечения наглядности учебники содержат большое количество изображений живых существ, фотографий девушек без хиджабов, учебных текстов и диалогов, которые отражают недозволенные, греховные, с точки зрения ислама, взаимоотношения русских людей и вызывают осуждение у мусульман.

Так, в исследовании М. Моазами и Т.Г. Ткач установлено, что иранские студенты-филологи, изучающие русский язык на родине, испытывают культурный шок при осмыслении учебных диалогов между русскими мужчинами и женщинами из российских учебных пособий. Обучающихся потрясает, что героями диалогов выступают лица противоположного пола, не являющиеся близкими родственниками, а также возможность ведения таких диалогов в необщественном месте [Моазами, Ткач, 2011, с. 42].

Об этом же писала преподаватель Е. Крисанова, работающая с иранцами в Москве. Она отмечала, что в процессе аудирования одного из учебных диалогов учащиеся были возмущены неприличным, по их мнению, поступком иностранца, который на автобусной остановке предложил незнакомой русской девушке поболтать, чтобы потренировать свой русский язык и скоротать время в ожидании транспорта: «А что, в России можно знакомиться с девушкой на остановке?», - произнес потрясенный иранец. - «Я же хороший человек и не хочу жениться!» (Крисанова Е. Братья-мусульмане. 22.01.2014. URL: http://ohrussian.com/bez-rubriki/ bratya-musulmane.html).

Объяснение этой реакции находим в работах ученых-востоковедов. В них показано, что в исламском обществе религия определяет систему взаимоотношений и социальных ролей мужчины и женщины и ограничивает свободу последней в общественных местах и быту. Подробно эти особенности охарактеризованы, например, в статьях Д. Еремеева. Приведем некоторые обобщения, представленные в его работах.

Женщина, с точки зрения мусульман, принадлежит отцу или мужу и потому не может брать на себя какие-либо обязательства без их разрешения (учиться, работать, заключать брак, свидетельствовать в суде, делать медицинскую операцию, передвигаться по городу и т. п.) и находиться наедине с мужчиной, который не является ее родственником, в необщественном месте [Еремеев, 1989б, c. 58-60]. Эти требования могут трактоваться весьма жестко.

Живет мусульманка на своей половине дома, куда не входят чужие мужчины. Она никогда не садится с ними за один стол или на одну скамью, не заходит в кафе, предназначенное для мужчин, ездит на специальных автобусах, живет в гостиницах на особых этажах и посещает концерты и парки в «дамские часы», чтобы исключить случайные встречи с посторонними мужчинами.

Учеба и карьера для мусульманки не являются приоритетной жизненной целью. Многие профессии запретны для нее, так как не согласуются с ее правовым статусом (например, профессия юриста, судьи) или требуют контактов с чужими мужчинами (например, профессия инженера, геолога, археолога, официантки и др.). Она может работать лишь там, где коллектив исключительно женский: на ткацких, швейных предприятиях, в женских школах, кафе и т. п. [Еремеев, 1989б, с. 60].

Сватовство у мусульман осуществляется только через родственников. Инициаторами брака являются родители жениха. Свадьба невозможна +++без брачного договора, и до его заключения жениху не разрешается общаться с невестой [Еремеев, 1989a, с. 53-55; Еремеев, 1989б, с. 59]. Празднуют свадьбу истинно верующие жених и невеста в разных компаниях и в разные дни, так как законы шариата запрещают совместное веселье мужчин и женщин.

Знакомства без посредников на улице, в парке, кино мусульманами осуждаются. Мужчина никогда не заговорит с незнакомой женщиной на улице, так как знает, что это породит конфликт с мужчинами ее семьи. Если же женщина обменяется несколькими словами со случайным прохожим, она становится объектом сплетен и пересудов [Еремеев, 1989б, c. 59]. При знакомстве мужчина не может поцеловать ни щеку, ни руку женщины. На Западе это считается общепринятым, но в исламских странах категорически неприемлемым [Сканави, 2004, с. 70].

Для защиты женщины от посторонних мужчин в исламском обществе используется 
специальная одежда. Она представляет собой различные накидки (хиджаб, паранджа, абайя, чадра, джильбаб, бурка и др.), которые позволяют скрыть от посторонних глаз все тело женщины, включая лицо, руки и ноги. Короткие юбки и шорты осуждаются [Еремеев, 1989б, с. 58]. Для мужчин минимум, который должен быть покрыт одеждой, - это тело между пупком и коленом. Однако в иллюстрациях универсальных учебников РКИ, рассчитанных на «абстрактного» иностранца, эти требования к внешнему виду, как уже говорилось, не соблюдаются, что вызывает смущение и дискомфорт у мусульманских учащихся.

Кроме политики половой сегрегации, в исламском обществе культивируется превосходство мужского пола. На узкой дороге, в дверях женщина не имеет права обгонять мужчину, она должна пропустить его вперед. Не принято уступать ей место и в общественном транспорте [Еремеев, 1989a, с. 52].

В исламском обществе женщину постоянно контролирует отец, брат или муж. Ей часто не разрешают выходить из дома одной, без сопровождения близких родственников мужского пола. Причем даже ребенок мужского пола на основании своего гендерного статуса может приказывать взрослой женщине [Еремеев, 1989а, с. 52; Еремеев, 1989б, с. 60] и считаться ее достойным, полноправным сопровождающим в общественных местах. Нарушителей гендерного запрета на посещение общественных мест строго наказывают, вплоть до смертной казни.

Неравноправный тип отношений порождает гендерную специфику в коммуникативном поведении мусульман на родном языке, которая может оказывать интерферирующее влияние на их русскую речь. В частности, разговор арабского мужчины с арабской женщиной - это общение вышестоящего человека с нижестоящим. Арабский мужчина более свободен в коммуникации и чаще инициирует диалог на арабском и русском языках (даже на начальном этапе обучения). Его публичная речь экспрессивна, образна и насыщена комплиментами, поскольку красноречие является для арабов одним из необходимых качеств настоящего мужчины [Сканави, 2004, с. 69]. Он активно использует жесты в общении, часто прикасается к собеседнику и пожимает ему руку, выражая свою симпатию и доверие. Однако прикосновения к арабке (не родственнице) в ходе беседы недопустимы, они будут восприняты как оскорбление.

В отличие от мужчины арабская женщина не может начать разговор первой, она более сдержанна и осторожна в своих высказываниях, и ей требуется больше времени на адаптацию в российской образовательной среде. Ее коммуникативная дистанция при общении с другими женщинами и мужчинами в особенности больше, чем между собеседниками-мужчинами [Кротова, 2012a, с. 57-58; 2015 , с. 83-84, 134]. В русской же культуре коммуникативные контакты между полами происходят на равных. В связи с этим ситуации общения между мужчинами и женщинами в русском обществе непривычны и сложны для понимания арабов и других мусульман, а потому нуждаются в разъяснении и специальном тренинге [Кротова, 2015, с. 138].

Идеальная мусульманская женщина - это образцовая жена, мать и хозяйка. Скромность ее главное достоинство. Увлечение нарядами, наличие поклонников и флирт с ними осуждаются. Брак считается священной обязанностью всех мусульман, а безбрачие - преступлением перед обществом. «Худший из мертвых тот, кто умер холостым», - утверждает исламский хадис. Спрос на невест в мусульманских странах превышает предложение, девушек выдают замуж рано (с 9-13 лет), поэтому «старых дев» практически нет [Еремеев, 1989a, с. 53; Еремеев, 1989б, с. 60].

Несмотря на то что ислам узаконил многоженство и временные браки, которые могут заключаться даже на один день, нравственное поведение полов регламентируется строгим кодексом приличий. В мусульманских странах не целуются и не обнимаются на людях. Любовь, даже между супругами, скрывается от посторонних глаз. Супруги редко появляются вместе. Муж старается не говорить о своей жене и даже не упоминать ее имя [Еремеев, 1989а, с. 52-54; Еремеев, 1989б, c. 59-60].

Предосудительным считается у мусульман и вопрос о здоровье жены знакомого или друга, подарок ей по случаю праздника, дня рождения [Еремеев, 1989б, с. 60], что также следует учитывать преподавателю в процес- 
се изучения материала универсального учебника РКИ.

Резюмируя сказанное по данному вопросу, подчеркнем, что в научной литературе проблема понимания студентами-мусульманами русских гендерных отношений, отраженных в учебниках и пособиях по РКИ, ранее подробно не рассматривалась. Однако, опираясь на работы востоковедов, отдельные замечания преподавателей, можно предположить, что критическое, дискомфортное восприятие этой категорией учащихся некоторых учебных диалогов, текстов и иллюстраций на гендерную тему связано с причинами не языкового, а культурологического характера. Оно обусловлено принципиальными различиями в системе гендерных отношений и социальных ролей мужчины и женщины в разных культурах и наиболее явно обнаруживается при освоении учебных материалов студентами из традиционных мусульманских стран (Саудовской Аравии, Пакистана, Ирака, Ирана, Палестины и др.).

\section{Заключение}

В настоящее время обучение студентовмусульман на подготовительных факультетах российских вузов повсеместно осуществляется с опорой на универсальные учебники и пособия по РКИ, которые позволяют студентам сформировать основы вторичной коммуникативной и межкультурной компетенций на русском языке. Однако отдельные тексты, диалоги, задания и иллюстрации из таких учебников, рассказывающие о русских гендерных отношениях, нередко вызывают негативную реакцию и отторжение у учащихся, исповедующих ислам.

Это объясняется тем, что авторы универсальных учебников и пособий по РКИ ориентируются на «абстрактного» иностранца и не учитывают религиозной специфики обучающихся, принципиальных различий в организации современной российской жизни и жизни мусульманских стран. Они также стремятся приблизить содержание учебников к реальной российской действительности, сделать их актуальными, интересными, проблемными, чтобы вызвать у студентов коммуникативную реакцию. С этой целью в учебники РКИ мо- гут включаться материалы, неоднозначно интерпретируемые с точки зрения традиционных общечеловеческих и российских ценностей и даже отражающие переживаемый современной Россией нравственный кризис.

Отсутствие взаимопонимания между мужчинами и женщинами, фривольный характер их отношений, распространенность внебрачных связей - все эти неприглядные черты российского общества конца XX - XXI в., как уже было показано на примере «Дороги в Россию», обнаруживаются в современной учебной литературе для иностранцев. Мусульмане воспринимают их крайне негативно, что обусловлено религиозной спецификой их обществ и особенностями социальных ролей в них мужчины и женщины. При этом представители мусульманских стран не знают, какие нравственные и семейные ценности традиционны для россиян и одобряются ими, не улавливают эмоционального отношения авторов учебников к персонажам текстов и часто делают неадекватные моральные выводы.

В этих ситуациях преподавателю следует не игнорировать реакцию мусульман, а выяснять основания их оценки и учитывать полученную информацию в процессе дальнейшей работы. Ряд проблемных материалов нужно исключать из учебного процесса (при необходимости компенсируя их другими), ряд - сопровождать культурологическими комментариями.

Кроме того, в силу религиозных, национальных, возрастных или личных особенностей мусульмане могут быть не готовы публично обсуждать нравственные проблемы личного, семейного характера. В этих случаях им нужно предлагать нейтральные в психологическом отношении тексты и задания, так как игнорирование их позиции может привести к конфликту в межкультурном общении на уроке и отрицательно скажется на мотивации и результатах обучения.

Как известно, все люди с удовольствием изучают то, что им нравится. Поэтому учебники РКИ не должны шокировать студентов-мусульман, они должны нравиться им, вызывать интерес, формировать положительное мнение о России, оптимизировать их общение с носителями русского языка. 


\section{СПИСОК ЛИТЕРАТУРЫ}

Дастамуз С., 2017. Использование учебников по РКИ при обучении русскому языку иранцев в университете «Аль-Захра» // Русский язык за рубежом (специальный выпуск). Русистика Ирана. С. 12-15. URL: https://journal-rla. pushkininstitute.ru/files/Иран_развороты.pdf

Еремеев Д., 1989а. Женщина и ислам // Азия и Африка сегодня. № 1. С. 51-55.

Еремеев Д., 1989б. Женщина и ислам // Азия и Африка сегодня. № 2. С. 58-62.

Кротова Т. А., 2012а. Гендерные особенности межкультурной коммуникации в арабском мире и их учет в процессе обучения русскому языку как иностранному // Русский язык в межкультурной коммуникации : материалы Международ. науч.-практ. конф., посвящ. 30летию каф. практич. рус. яз. Иван. гос. ун-та (г. Иваново, 6 сент. 2012 г.) / отв. ред. Ф. Ф. Фархугдинова. Иваново : Изд-во Иван. гос. ун-та. С. 55-59.

Кротова Т. А., 2012б. Традиции исламской системы образования в процессе обучения арабских учащихся русскому языку // Проблемы преподавания филологических дисциплин иностранным учащимся : материалы II Международ. науч.-метод. конф. (г. Воронеж, 26-27 янв. 2012 г.) / отв. ред. Е. А. Пляскова. Воронеж : Истоки. С. 355-361.

Кротова Т. А., 2014. Обучение русскому языку в условиях полиэтнической группы: проблемы педагогического взаимодействия // Вестник Челябинского государственного педагогического университета. № 3. С. 89-101.

Кротова Т. А., 2015. Этноориентированная система лингвокультурной адаптации арабских учащихся в практике обучения РКИ : дис. ... канд. пед. наук. М. 243 с.

Моазами М., Ткач Т. Г., 2011. Культурные и психологические трудности изучения русского языка в мусульманской аудитории (на примере иранских учащихся) // Вестник Центра международного образования Московского государственного университета. Филология. Культурология. Педагогика. Методика. № 2. С. 41-45.

Сейд Х. 3., Муса А., 2015. Национальная культура и обучение иностранным языкам в мусульманских странах // Символ науки. № 12-2. C. $266-269$.

Сергеева А. В., 2005. Русские : стереотипы поведения, традиции, ментальность. 3-е изд. М. : Флинта : Наука. 313 c.

Сканави А., 2004. Арабский этикет. Языковые изыски, которые всегда на пользу // Азия и Африка сегодня. № 7. С. 68-72.
Шоджаи М., 2007. Преподавание русского языка в Иране (на примере подготовительного курса) // Русский язык за рубежом. № 4. С. 92-96.

Юнал К., Юнусов И., 2015. Специфика восприятия русской литературы в мусульманских сообществах (на примере Турции) // Русский язык за рубежом. № 3. С. 89-96.

Юнусов И. Ш., Озтюрк М., 2012. О некоторых особенностях преподавания русской литературы турецким студентам // Филология и культура. №2 (28). C. 161-164.

\section{ИСТОчники}

Антонова и др., 2001 - Антонова В. Е., Нахабина М. М., Сафронова М. В., Толстых А. А. Дорога в Россию. Учебник русского языка (элементарный уровень) на персидском языке / пер. Алиреза Акбарипур. М. : Изд-во ЦМО МГУ ; СПб. : Златоуст, 2001. 344 с.

Антонова и др., 2003a - Антонова В. Е., Нахабина М. М., Сафронова М. В., Толстых А. А. Дорога в Россию. Учебник русского языка (элементарный уровень). М. : Изд-во ЦМО МГУ ; СПб. : Златоуст, 2003.344 с.

Антонова и др., 20036 - Антонова В. Е., Нахабина М. М., Сафронова М. В., Толстых А. А. Дорога в Россию. Учебник русского языка (элементарный уровень). Грамматический комментарий и словарь к учебнику для говорящих на персидском языке / пер. Алиреза Акбарипур. М. : Изд-во ЦМО МГУ ; СПб. : Златоуст, 2003. $108 \mathrm{c}$.

Антонова и др., 2004 - Антонова В. Е., Нахабина М. М., Толстых А. А. Дорога в Россию. Учебник русского языка (базовый уровень). М. : Изд-во ЦМО МГУ ; СПб. : Златоуст, 2004. $256 \mathrm{c}$.

Антонова и др., 2006а - Антонова В. Е., Нахабина М. М., Толстых А. А. Дорога в Россию. Учебник русского языка (первый уровень). В 2 т. Т. 1. СПб. : Златоуст, 2006.200 с.

Антонова и др., $2006 б$ - Антонова В. Е., Нахабина М. М., Толстых А. А. Дорога в Россию. Учебник русского языка (первый уровень). В 2 т. Т. 2. СПб. : Златоуст, 2006. 184 с.

\section{REFERENCES}

Dastamuz S., 2017. Ispolzovanie uchebnikov po RKI pri obuchenii russkomu yazyku irantsev $\mathrm{v}$ universitete «Al-Zakhra» [Textbooks RFL in the Program of Teaching the Russian Language to the Iranian Students in Alzahra University]. 
Russkiy yazyk za rubezhom (spetsialnyy vypusk). Rusistika Irana. [Russian Language Abroad (Special Issue). Iranian Russian Studies], pp. 12-15. URL: https://journalrla.pushkininstitute.ru/files/Iran_razvoroty.pdf.

Eremeev D., 1989a. Zhenshchina i islam [Woman and Islam]. Aziya i Afrika segodnya [Asia and Africa Today], no. 1, pp. 51-55.

Eremeev D., 1989b. Zhenshchina i islam [Woman and Islam]. Aziya i Afrika segodnya [Asia and Africa Today], no. 2, pp. 58-62.

Krotova T.A., 2012a. Gendernye osobennosti mezhkulturnoy kommunikatsii v arabskom mire i ikh uchet $\mathrm{v}$ protsesse obucheniya russkomu yazyku kak inostrannomu [Gender Features of Intercultural Communication in the Arab World and Their Consideration in the Process of Teaching Russian as a Foreign Language]. F.F. Farkhutdinova, ed. Russkiy yazyk $v$ mezhkulturnoy kommunikatsii: materialy Mezhdunarod. nauch.-prakt. konf., posvyashch. 30-letiyu kaf. praktich. rus. yaz. Ivan. gos. unta (g. Ivanovo, 6 sent. 2012 g.) [Russian Language in Intercultural Communication. Proceedings of the International Scientific and Practical Conference Dedicated to the $30^{\text {th }}$ Anniversary of the Department of Practical Russian Language of Ivanovo State University (Ivanovo, September 6, 2012)]. Ivanovo, Izd-vo Ivanovskogo gosudarstvennogo universiteta, pp. 55-59.

Krotova T.A., 2012b. Traditsii islamskoy sistemy obrazovaniya $\mathrm{v}$ protsesse obucheniya arabskikh uchashchikhsya russkomu yazyku [Traditions of the Islamic Education System in the Process of Teaching Russian to Arab Students]. Plyaskova E.A., ed. Problemy prepodavaniya filologicheskikh distsiplin inostrannym uchashchimsya: materialy II Mezhdunarod. nauch.-metod. konf. (g. Voronezh, 26-27 yanv. 2012 g.) [Problems of Teaching Philological Disciplines to Foreign Students. Proceedings of the $2^{\text {nd }}$ International Scientific and Methodical Conference (Voronezh, January 26-27, 2012]. Voronezh, Istoki Publ., pp. 355-361.

Krotova T.A., 2014. Obuchenie russkomu yazyku v usloviyakh polietnicheskoy gruppy: problemy pedagogicheskogo vzaimodeystviy [Learn Russian Language in Terms Multiethnic Groups of the Problem of Pedagogical Interaction]. Vestnik Chelyabinskogo gosudarstvennogo pedagogicheskogo universiteta [Herald of Chelyabinsk State Pedagogical University], no. 3, pp. 89-101.

Krotova T.A., 2015. Etnoorientirovannaya sistema lingvokulturnoy adaptatsii arabskikh uchashchikhsya $v$ praktike obucheniya RKI: dis.... kand. ped. nauk [Ethno-Oriented System of Linguistic and Cultural Adaptation of Arab Students in the Practice of Teaching RFL. Cand. ped. sci. diss.]. Moscow. 243 p.

Moazami M., Tkach T.G., 2011. Kulturnye i psikhologicheskie trudnosti izucheniya russkogo yazyka $\mathrm{v}$ musulmanskoy auditorii (na primere iranskikh uchashchikhsya) [Cultural and Psychological Problems of Teaching Russian Language Muslim Audience (Iranian Students)]. Vestnik Tsentra mezhdunarodnogo obrazovaniya Moskovskogo gosudarstvennogo universiteta. Filologiya. Kulturologiya. Pedagogika. Metodika, no. 2, pp. 41-45.

Seyd Kh.Z., Musa A., 2015. Natsionalnaya kultura i obuchenie inostrannym yazykam $\mathrm{v}$ musulmanskikh stranakh [National Culture and Foreign Language Teaching in Muslim Countries]. Simvol nauki, no. 12-2, pp. 266-269.

Sergeeva A.V., 2005. Russkie: stereotipy povedeniya, traditsii, mentalnost [The Russians: Stereotypes of Behaviour, Traditions, Mentality]. Moscow, Flinta Publ., Nauka Publ. 313 p.

Skanavi A., 2004. Arabskiy etiket. Yazykovye izyski, kotorye vsegda na polzu [Arabic Etiquette. Language Delights, Which Are Always Good]. Aziya i Afrika segodnya [Asia and Africa Today], no. 7, pp. 68-72.

Shodzhay M., 2007. Prepodavanie russkogo yazyka v Irane (na primere podgotovitelnogo kursa) [Teaching of Russian Language in Iran (On the Example of the Preparatory Course)]. Russkiy yazyk za rubezhom [Russian Language abroad], no. 4, pp. 92-96.

Yunal K., Yunusov I., 2015. Spetsifika vospriyatiya russkoy literatury $\mathrm{V}$ musulmanskikh soobshchestvakh (na primere Turtsii) [The Specificity of the Perception of Russian Literature in Muslim Communities (On the Example of Turkey)]. Russkiy yazyk za rubezhom [Russian Language Abroad], no. 3, pp. 89-96. Yunusov I.Sh., Oztyurk M., 2012. O nekotorykh osobennostyakh prepodavaniya russkoy literatury turetskim studentam [Some Features of Teaching Russian Literature Turkish Students]. Filologiya i kultura [Philology and Culture], no. 2 (28), pp. 161-164.

\section{SOURCES}

Antonova V.E., Nakhabina M.M., Safronova M.V., Tolstykh A.A. Doroga v Rossiyu. Uchebnik russkogo yazyka (elementarnyy uroven) na persidskom yazyke [The Road to Russia: 
Russian Language Textbook (Elementary Level). In Persian]. Moscow, Izd-vo TsMO MGU, Saint Petersburg, Zlatoust Publ., 2001. $344 \mathrm{p}$.

Antonova V.E., Nakhabina M.M., Safronova M.V., Tolstykh A.A. Doroga v Rossiyu. Uchebnik russkogo yazyka (elementarnyy uroven) [The Road to Russia: Russian Language Textbook (Elementary Level)]. Moscow, Izdvo TsMO MGU, Saint Petersburg, Zlatoust Publ., 2003. 344 p.

Antonova V.E., Nakhabina M.M., Safronova M.V., Tolstykh A.A. Doroga v Rossiyu. Uchebnik russkogo yazyka (elementarnyy uroven). Grammaticheskiy kommentariy $i$ slovar $k$ uchebniku dlya govorya shchikh na persidskom yazyke [The Road to Russia: Russian Language Textbook (Elementary Level). Grammar Review and Vocabulary to the Textbook for Speakers of the Persian Language]. Moscow,
Izd-vo TsMO MGU, Saint Petersburg, Zlatoust Publ., 2003. 108 p.

Antonova V.E., Nakhabina M.M., Tolstykh A.A. Doroga v Rossiyu. Uchebnik russkogo yazyka (bazovyy uroven) [The Road to Russia: Russian Language Textbook (Basic Level)]. Moscow, Izd-vo TsMO MGU, Saint Petersburg, Zlatoust Publ., 2004. 256 p.

Antonova V.E., Nakhabina M.M., Tolstykh A.A. Doroga v Rossiyu. Uchebnik russkogo yazyka (pervyy uroven). V2 t. T. 1 [The Road to Russia: Russian Language Textbook (First Level). In 2 vols. Vol. 1]. Saint Petersburg, Zlatoust Publ., 2006. 200 p.

Antonova V.E., Nakhabina M.M., Tolstykh A.A. Doroga v Rossiyu. Uchebnik russkogo yazyka (pervyy uroven). V2 t. T. 2 [The Road to Russia: Russian Language Textbook (First Level). In 2 vols. Vol. 2]. Saint Petersburg, Zlatoust Publ., 2006. 184 p.

\section{Information about the Author}

Natalya A. Vostryakova, Candidate of Sciences (Philology), Associate Professor, Department of Russian Language, Volgograd State Technical University, Prosp. V.I. Lenina, 28, 400005 Volgograd, Russia, vostrjakova@yandex.ru, https://orcid.org/0000-0001-6795-6929

\section{Информация об авторе}

Наталья Анатольевна Вострякова, кандидат филологических наук, доцент кафедры русского языка, Волгоградский государственный технический университет, просп. им. В.И. Ленина, 28, 400005 г. Волгоград, Россия, vostrjakova@yandex.ru, https://orcid.org/0000-0001-6795-6929 